\title{
Studies on Bioefficacy, Phytotoxicity and Economic Management of Alternaria Leaf Spot of Cauliflower
}

\author{
Suresh D. Ekabote ${ }^{1 *}$, U. Divyajyothi $^{2}$, H. Ravindra ${ }^{3}$ and Jeevan $^{4}$ \\ ${ }^{1}$ Department of Crop Protection, College of Horticulture, Hiriyur, University of Agricultural and \\ Horticultural sciences, Shivamogga -580 005, India \\ ${ }^{2}$ College of Agriculture University of Agricultural and Horticultural sciences, \\ Shivamogga -580 005, India \\ ${ }^{3}$ AICRP (N), University of Agricultural and Horticultural sciences, Shivamogga -580 005, India \\ ${ }^{4}$ College of Horticulture, Hiriyur, University of Agricultural and Horticultural sciences, \\ Shivamogga -580 005, India \\ *Corresponding author
}

\section{A B S T R A C T}

\begin{tabular}{|l|}
\hline Ke y w or d s \\
Cauliflower, Leaf \\
spot, Phytotoxicity, \\
Bioefficacy.
\end{tabular}

Alternaria leaf spot of cauliflower caused by Alternaria brassicae (Berk.) Sacc. has become major constraint in Cauliflower growing areas. A field experiment was carried out for two year at college of Horticulture, Hiriyur for bio efficacy and phytotoxicity of Kavach against foliar disease of cauliflower. Among the fungicides tested spray of chlorothalonil $75 \%$ WP @ 2 $\mathrm{g} /$ lit recorded lowest percent disease index (7.25) and highest curd yield (10.9 t/ha followed by chlorothalonil 75\% WP @ 1.5g/lit (9.25 PDI) and chlorothalonil 75\% WP @ 1g/lit (10.67PDI).

\section{Introduction}

Cauliflower (Brassica oleracea var. botrytis) belongs to genus Brassica and family Brassicaceae. It is now grown in many countries like China, India, Spain, Italy, France, U.S.A. Pakistan and U.K. In India cauliflower cultivated on an area $434 \mathrm{~m}$ ha, with production $(8573 \mathrm{mt})$ and the productivity (19.8 $\mathrm{mt} / \mathrm{ha})$ (Anonymous, 2013). Cauliflower crop is affected by many fungal, bacterial and viral plant pathogens amongst them fungal disease leaf spot/ blight caused by Alternaria brassicae is one of the most destructive diseases causing quantitative losses. At least $20 \%$ of agricultural spoilage is caused by Alternaria spp. Most severe losses may reaches upto $80 \%$ of yield.

Alternaria leaf spot of cauliflower is difficult to control because there are several sources of inoculum including infected seed, plant debris in the soil and nearby infected cruciferous crops and the disease spread rapidly during warm and wet conditions affecting significant proportion of the cabbage crop. Therefore, keeping in view the economic losses caused by this disease, the present study was aimed at 
determining an effective management of Alternaria blight in India.

\section{Materials and Methods}

A field experiment on bio efficacy and phytotoxicity of Kavach against foliar diseases of cauliflower was conducted at College of Horticulture, Hiriyur during 201213 and 2013-14. The experiments consisted of 7 treatments viz., untreated check, Chlorothalonil 75WP(1.0g), Chlorothalonil 75WP(1.5g), Chlorothalonil 75WP(2.0g), Mancozeb(2.0g), Zineb(2.0g), standard check (copper oxychloride $3.0 \mathrm{~g}$ ) and was laid-out in Randomized Block Design with three replication. A susceptible variety was used in the present investigations. The variety was grown as per packages of practices for higher yields. Treatments were imposed at beginning of the disease appearance. Spray schedule was repeated at 15 days intervals. The Per cent disease index (PDI) was computed by selecting five plants at random and recording alternaria leaf spot severity as per $0-5$ scale (Verma and Saharan, 1994). Average of all spray has been given in this and the data was statistically analyzed after suitable transformations.

The per cent disease index (PDI) was calculated by the formula (Sikdar and krishnaswami, 1980)

Sum of the individual disease ratings Per cent

Disease index $(\mathrm{PDI})=$

Number of leaves observed $x$ Maximum disease grade

\section{Results and Discussion}

Results (Table 1) revealed that the two year pooled data of per cent disease index of alternaria leaf spot and curd yield of cauliflower differed significantly among the treatments.

\section{Percent disease index}

During 2012-13, there were much significant differences among the treatments imposed with respect to the reduction of foliar diseases. Among the different treatments, the chlorothalonil 75\% WP @ 2.0 g/l has recorded lowest PDI (8.83) which is followed by chlorothalonil 75\% WP @ 1.5g/lit. However this treatment is on par with other treatments, but it is significantly superior over Mancozeb@2.0 g/l in managing leaf spot (15.58) (Table 1). During the second year spray there is no much significant differences among the treatments imposed with respect to the reduction of foliar diseases compare to first season. The diseases severity of leaf spot is less with PDI of 5.67 has been observed after second spray with chlorothalonil $75 \%$ WP @ $2.0 \mathrm{~g} / 1$ which is followed by chlorothalonil 75\% WP @ 1.5g/lit (7.50) however this treatment is on par with other treatments, but it is significantly superior over Zineb @ 2.0 g/l in managing leaf spot (18.50) (Table 1). It has been found that, per cent disease control of leaf spot was 69.35 in the plot sprayed with chlorothalonil 75\% WP @ $1.5 \mathrm{~g} /$ lit @ $2.0 \mathrm{~g} / \mathrm{l}$ which is superior over Zineb @ $2.0 \mathrm{~g} / \mathrm{l}$ (Table 1).

These results are close to the finding of Arun kumar (2008) reported that chlorothalonil $(0.2 \%)$ and mancozeb $(0.25)$ were next to hexaconazole $(0.1 \%)$ interms of efficacy in controlling the leaf blight of chrysanthemum caused by Alternaria alternate. Kammana et.al (2010) reported that chlorothalonil $(0.20 \%)$ concentration in effectively controlled Alternaria leaf blight under field condition.

\section{Curd yield}

The results on curd yield of cauliflower showed significant difference due to the effect of different treatments during 2012-13 and 2013-14 as presented in table 1. 
Table.1 Bio - efficacy of Kavach 75 WP against foliar disease of cauliflower during 2012-13 and 2013-14 (Average of all 3 sprays)

\begin{tabular}{|c|c|c|c|c|c|c|c|c|}
\hline S. No. & Treatments & Concentration & \multicolumn{3}{|c|}{ Disease severity (\%) } & \multicolumn{3}{|c|}{ Yield (t/ha) } \\
\hline & & & 2012-13 & 2013-14 & Pooled & 2012-13 & 2013-14 & Pooled \\
\hline 1 & Untreated check & - & $\begin{array}{l}22.83 \\
(4.83)\end{array}$ & $\begin{array}{l}31.17 \\
(5.61)\end{array}$ & $\begin{array}{c}27 \\
(5.22)\end{array}$ & $\begin{array}{c}1.67 \\
(1.47)\end{array}$ & $\begin{array}{c}1.83 \\
(1.52)\end{array}$ & $\begin{array}{c}1.8 \\
(1.5)\end{array}$ \\
\hline 2 & Chlorothalonil 75WP & $1.0 \mathrm{~g}$ & $\begin{array}{l}11.83 \\
(3.51)\end{array}$ & $\begin{array}{c}9.50 \\
(3.16)\end{array}$ & $\begin{array}{l}10.67 \\
(3.34)\end{array}$ & $\begin{array}{c}7.33 \\
(2.80)\end{array}$ & $\begin{array}{c}8.83 \\
(3.05)\end{array}$ & $\begin{array}{c}8.1 \\
(2.9)\end{array}$ \\
\hline 3 & Chlorothalonil 75WP & $1.5 \mathrm{~g}$ & $\begin{array}{l}11.00 \\
(3.39)\end{array}$ & $\begin{array}{c}7.50 \\
(2.82)\end{array}$ & $\begin{array}{c}9.25 \\
(3.11)\end{array}$ & $\begin{array}{c}9.00 \\
(3.08)\end{array}$ & $\begin{array}{c}9.83 \\
(3.21)\end{array}$ & $\begin{array}{c}9.4 \\
(3.1)\end{array}$ \\
\hline 4 & Chlorothalonil 75WP & $2.0 \mathrm{~g}$ & $\begin{array}{c}8.83 \\
(3.05)\end{array}$ & $\begin{array}{c}5.67 \\
(2.48)\end{array}$ & $\begin{array}{c}7.25 \\
(2.77)\end{array}$ & $\begin{array}{l}10.50 \\
(3.31)\end{array}$ & $\begin{array}{l}11.33 \\
(3.44)\end{array}$ & $\begin{array}{l}10.9 \\
(3.4)\end{array}$ \\
\hline 5 & Mancozeb & $2.0 \mathrm{~g}$ & $\begin{array}{l}15.58 \\
(4.01)\end{array}$ & $\begin{array}{l}13.33 \\
(3.72)\end{array}$ & $\begin{array}{l}14.46 \\
(3.87) \\
\end{array}$ & $\begin{array}{c}5.50 \\
(2.45)\end{array}$ & $\begin{array}{c}4.50 \\
(2.23)\end{array}$ & $\begin{array}{c}5.0 \\
(2.3)\end{array}$ \\
\hline 6 & Zineb & $2.0 \mathrm{~g}$ & $\begin{array}{l}17.67 \\
(4.26)\end{array}$ & $\begin{array}{l}18.50 \\
(4.36)\end{array}$ & $\begin{array}{l}18.08 \\
(4.31)\end{array}$ & $\begin{array}{c}4.33 \\
(2.20)\end{array}$ & $\begin{array}{c}3.83 \\
(2.08)\end{array}$ & $\begin{array}{c}4.1 \\
(2.1)\end{array}$ \\
\hline 7 & standard check(copper oxychloride) & $3.0 \mathrm{~g}$ & $\begin{array}{l}17.25 \\
(4.21) \\
\end{array}$ & $\begin{array}{l}16.67 \\
(4.14) \\
\end{array}$ & $\begin{array}{l}16.96 \\
(4.18) \\
\end{array}$ & $\begin{array}{c}5.67 \\
(2.48) \\
\end{array}$ & $\begin{array}{c}5.83 \\
(2.51) \\
\end{array}$ & $\begin{array}{c}5.8 \\
(2.5)\end{array}$ \\
\hline \multirow{2}{*}{\multicolumn{3}{|c|}{$\begin{array}{c}\text { S.Em } \pm \\
\text { CD at } 5 \%\end{array}$}} & 0.84 & 1.21 & 1.44 & 0.41 & 0.41 & 0.41 \\
\hline & & & 2.56 & 3.66 & 3.11 & 2.45 & 1.23 & 1.84 \\
\hline
\end{tabular}

Table.2 Impact of Kavach on cauliflower during 2012-13

\begin{tabular}{|c|c|c|c|c|c|c|c|c|c|c|c|c|c|c|c|c|c|c|c|c|c|c|c|c|c|c|c|c|c|c|c|}
\hline \multirow[t]{3}{*}{ Treatments } & \multirow{3}{*}{$\begin{array}{c}\text { Dose }(\mathrm{g} \\
\text { or } \\
\mathrm{ml} / \mathrm{lit}) \\
\end{array}$} & \multicolumn{30}{|c|}{ Score value } \\
\hline & & \multicolumn{6}{|c|}{ 1DAA } & \multicolumn{6}{|c|}{$3 \mathrm{DAA}$} & \multicolumn{6}{|c|}{$5 \mathrm{DAA}$} & \multicolumn{6}{|c|}{$7 \mathrm{DAA}$} & \multicolumn{6}{|c|}{$10 \mathrm{DAA}$} \\
\hline & & $\mathbf{A}$ & B & $\mathbf{C}$ & D & $\mathbf{E}$ & $\mathbf{F}$ & $\mathbf{A}$ & B & $\mathbf{C}$ & D & $\mathbf{E}$ & $\mathbf{F}$ & $\mathbf{A}$ & $\mathbf{B}$ & $\mathbf{C}$ & D & $\mathbf{E}$ & $\mathbf{F}$ & A & B & $\mathbf{C}$ & D & $\mathbf{E}$ & $\mathbf{F}$ & $\mathbf{A}$ & B & $\mathbf{C}$ & D & $\mathbf{E}$ & $\mathbf{F}$ \\
\hline Untreated check & - & 0 & 0 & 0 & 0 & 0 & 0 & 0 & 0 & 0 & 0 & 0 & 0 & 0 & 0 & 0 & 0 & 0 & 0 & 0 & 0 & 0 & 0 & 0 & 0 & 0 & 0 & 0 & 0 & 0 & 0 \\
\hline $\begin{array}{l}\text { Chlorothalonil } \\
75 \% \text { WP(Kavach) }\end{array}$ & $2.0 \mathrm{~g}$ & 0 & 0 & 0 & 0 & 0 & 0 & 0 & 0 & 0 & 0 & 0 & 0 & 0 & 0 & 0 & 0 & 0 & 0 & 0 & 0 & 0 & 0 & 0 & 0 & 0 & 0 & 0 & 0 & 0 & 0 \\
\hline $\begin{array}{l}\text { Chlorothalonil } \\
75 \% \text { WP(Kavach) }\end{array}$ & $4.0 \mathrm{~g}$ & 0 & 0 & 0 & 0 & 0 & 0 & 0 & 0 & 0 & 0 & 0 & 0 & 0 & 0 & 0 & 0 & 0 & 0 & 0 & 0 & 0 & 0 & 0 & 0 & 0 & 0 & 0 & 0 & 0 & 0 \\
\hline
\end{tabular}

A: leaf injury on tips and leaf surface; B: Wilting: C: leaf vein clearing; D: Necrosis; E: Epinasty; F: Hyponasty; DAA: Days after Application 
Table.3 Impact of Kavach on cauliflower during 2013-14

\begin{tabular}{|c|c|c|c|c|c|c|c|c|c|c|c|c|c|c|c|c|c|c|c|c|c|c|c|c|c|c|c|c|c|c|c|}
\hline \multirow[t]{3}{*}{ Treatments } & \multirow{3}{*}{\begin{tabular}{|c|} 
Dose \\
(g or \\
$\mathrm{ml} / \mathrm{lit}$ )
\end{tabular}} & \multicolumn{30}{|c|}{ Score value } \\
\hline & & \multicolumn{6}{|c|}{ 1DAA } & \multicolumn{6}{|c|}{$3 \mathrm{DAA}$} & \multicolumn{7}{|c|}{ 5DAA } & \multicolumn{5}{|c|}{ 7DAA } & \multicolumn{6}{|c|}{ 10DAA } \\
\hline & & $\mathbf{A}$ & $\mathbf{B}$ & $\mathbf{C}$ & D & $\mathbf{E}$ & $\mathbf{F}$ & $\mathbf{A}$ & $\mathbf{B}$ & $\mathbf{C}$ & $\mathbf{D}$ & $\mathbf{E}$ & $\mathbf{F}$ & $\mathbf{A}$ & $\mathbf{B}$ & $\mathbf{C}$ & $\mathbf{D}$ & $\mathbf{E}$ & $\mathbf{F}$ & $\mathbf{A}$ & $\mathbf{B}$ & $\mathbf{C}$ & $\mathbf{D}$ & $\mathbf{E}$ & $\mathbf{F}$ & $\mathbf{A}$ & $\mathbf{B}$ & $\mathbf{C}$ & $\mathbf{D}$ & $\mathbf{E}$ & $\mathbf{F}$ \\
\hline Untreated check & - & 0 & 0 & 0 & 0 & 0 & 0 & 0 & 0 & 0 & 0 & 0 & 0 & 0 & 0 & 0 & 0 & 0 & 0 & 0 & 0 & 0 & 0 & 0 & 0 & 0 & 0 & 0 & 0 & 0 & 0 \\
\hline $\begin{array}{l}\text { Chlorothalonil } \\
75 \% \text { WP(Kavach) }\end{array}$ & $2.0 \mathrm{~g}$ & 0 & 0 & 0 & 0 & 0 & 0 & 0 & 0 & 0 & 0 & 0 & 0 & 0 & 0 & 0 & 0 & 0 & 0 & 0 & 0 & 0 & 0 & 0 & 0 & 0 & 0 & 0 & 0 & 0 & 0 \\
\hline $\begin{array}{l}\text { Chlorothalonil } \\
75 \% \text { WP(Kavach) }\end{array}$ & $4.0 \mathrm{~g}$ & 0 & 0 & 0 & 0 & 0 & 0 & 0 & 0 & 0 & 0 & 0 & 0 & 0 & 0 & 0 & 0 & 0 & 0 & 0 & 0 & 0 & 0 & 0 & 0 & 0 & 0 & 0 & 0 & 0 & 0 \\
\hline
\end{tabular}

A: leaf injury on tips and leaf surface; B: Wilting: C: leaf vein clearing; D: Necrosis; E: Epinasty; F: Hyponasty; DAA: Days after

Standard disease rating scale of Alternaria leaf spot disease (0-5scale) for accessing PDI

\begin{tabular}{|c|c|}
\hline Scale & Per cent leaf area covered \\
\hline 0 & No disease \\
\hline 1 & $1-10 \%$ \\
\hline 2 & $11-25 \%$ \\
\hline 3 & $26-50 \%$ \\
\hline 4 & $51-75 \%$ \\
\hline 5 & $76-1005$ \\
\hline
\end{tabular}

For phytotoxicity studies

\begin{tabular}{|l|l|l|l|}
\hline S. No. & Treatments & g.a.i/lit of water & Formulation \\
\hline 1 & Untreated check & & \\
\hline 2 & Chlorothalonil 75\%WP(Kavach) & 1.50 & 2.0 \\
\hline 3 & Chlorothalonil 75\%WP(Kavach) & 3.00 & 4.0 \\
\hline
\end{tabular}


Among the different treatments chlorothalonil 75\% WP @ 2.0 g/l has recorded the highest curd yield of 10.50 t/ha followed by chlorothalonil 75\% WP @ 1.5g/lit (9.0t/ha). As per the results the chlorothalonil $75 \%$ WP @ $2.0 \mathrm{~g} / \mathrm{l}$ has recorded 52.45 per cent higher curd yield in compare to the standard chemical Mancozeb @ 2.0g/l. during 201213. During 2013-14, the comparative curd yield were also recorded significantly higher with the same treatment of chlorothalonil 75\% WP @ $2.0 \mathrm{~g} / \mathrm{l}$ has recorded the highest curd yield of 10.50 t/ha followed by chlorothalonil 75\% WP @1.5g/lit (9.0t/ha). As per the results the chlorothalonil $75 \% \mathrm{WP}$ @ $2.0 \mathrm{~g} / \mathrm{l}$ has recorded 52.45 per cent higher curd yield in compare to the standard chemical Mancozeb@2.0g/l. these results are in close to the findings of Singh and Bhowmik (1985) and Mishra, et al., (2009) (Tables 2 and 3).

\section{Phytotoxicity}

There were no phytotoxicity symptoms like Epinasty, hyponasty, vein clearing, yellowing, necrosis, leaf margin burning, rosseting and wilting were observed in different concentrations of chlorothalonil 75\% WP.

Based on the two years experimentation it has been found that, chlorothalonil 75\% WP @ @ $2.0 \mathrm{~g} / 1$ is most effective in management of foliar diseases (leaf spot) of cauliflower which is followed by the same fungicides @ $1.5 \mathrm{~g} / \mathrm{l}$ when compared to the other treatments. Chlorothalonil 75\% WP @ 2.0g/1 was found to be optimum dosage for management of foliar diseases and harvest of maximum yield. Chlorothalonil 75\% WP @ $4.0 \mathrm{~g} / \mathrm{l}$ was found to be no phytotoxic and safe to cauliflower crop.

\section{References}

Anonymous. Indian Horticulture database, 2013.

Kamanna, B.C., Shankarappa, T. H. and Arun Kumar., G. S., 2010, Evaluation of fungicides for the management of chrysanthemum leaf blight caused by Alternaria alternata (Fr.) Kessler. Plant Archives, 10 (2): 595-597.

Mishra, P.K., Rai, R.K., Saha, S., Pandey, K.K., Singh, R.P., and Rai, A.B. 2009, Effect of fungicides, botanicals and bioagents against leaf spot cauliflower caused by Alternaria brassicae. (Berk.) Sacc. Veg. Sci., 36 (3) pp: 356-359.

Sikdar, A.K., and Krishnaswami S., 1980, Assessment of leaf yield loss of two Mulberry varieties due to leaf spot disease. Indian Journal of Sericulture. pp 19: 9 - 12.

Singh, A., and Bhowmik, T.P. 1985, Persistence and efficacy of some common fungicide against Alternaria brassicae, the causal agent of leaf blight of rapeseed and mustard. Indian Phytopath. 38: 35-38.

Verma, P.R., and Saharan, G.S. 1994, Monograph on Alternaria diseases of crucifers. Saskatoon Research Station, Technical Bulletin 1994-6E, Agric AgriFood Canada, Saskatoon, Canada pp 162.

\section{How to cite this article:}

Suresh D. Ekabote, U. Divyajyothi, H. Ravindra and Jeevan. 2017. Studies on Bioefficacy, Phytotoxicity and Economic Management of Alternaria Leaf Spot of Cauliflower. Int.J.Curr.Microbiol.App.Sci. 6(9): 2585-2589. doi: https://doi.org/10.20546/ijcmas.2017.609.318 